\title{
EKSPERIMEN SOSIS SAYUR HASIL OLAHAN DARI SAYUR BROKOLI (Brassica oleracea L.) DAN WORTEL (Daucus carota L.)
}

\author{
M. RIZAL UMAMI ${ }^{1 *}$, GUNTORO ${ }^{1}$ \\ ${ }^{1}$ Jurusan Teknologi Pertanian, Politeknik Negeri Jember, Jl. Mastrip PO BOX 164 Kel. \\ Tegal Gede, Kec. Sumbersari, Kab. Jember, Jawa Timur, Indonesia. \\ *Email: rizalumami.mbipb.polije@gmail.com
}

\begin{abstract}
Sausage is mostly made of meat, fat, food binders, food filler, water, salt, and other seasonings. The most common meats used in making sausage are beef and chicken. The availability of the ingredient is one of the reasons in choosing the meat substances. Indeed, most people put beef and chicken on the top list of their favorite foods. Unfortunately, the price of meat is expensive. For that reason, there is a need to search precise substitutional substances for meat - the researcher occupied vegetables (broccoli and carrot) to substitute beef and chicken. In addition, it nutrients. This research is conducted quality requirement of vegetable sausage based on SNI 101-3820-1995. During the production process, the vegetables and the chicken were washed. Then the chicken was chopped off while the vegetable was sliced. The next step was boiling the vegetables and the chicken. After that vegetables and all the seasonings were mixed and mashed in order to get smooth dough. Measured amount of wheat flour, cornstarch, and other ingredients were, then, added to the processed materials and stirred thoroughly. The dough was put into dough sausage machine then push the dough to shape the sausage. The final step was to steam the sausage until it was well-cooked. The tests include organoleptic test, water content test, protein test, ash content test, carbohydrate test, fat test, microbiology test including E. Coli and mold test. The results of the tests are all good while the result of the carbohydrate test higher value than the standard.
\end{abstract}

Keywords: Sausage, Brassica, Daucus Carota, Experiment

\begin{abstract}
ABSTRAK
Sosis merupakan makanan yang terbuat dari daging, lemak, bahan pengikat, bahan pengisi, air, garam, dan bumbu-bumbu. Umumnya sosis dibuat dari daging sapi atau daging ayam, hal ini dikarenakan bahan tersebut banyak tersedia dipasaran dan disukai oleh semua kalangan. Melihat harga jual daging yang masih tergolong mahal dan menambah nilai gizi, maka perlu adanya pengganti bahan sapi atau ayam yaitu dengan menggunakan bahan dasar yang memiliki harga lebih ekonomis dan sesuai standar SNI. Penelitian ini bertujuan untuk membuat olahan sosis berbahan sayur dengan syarat mutu sosis berdasarkan SNI 1013820-1995. Pembuatan sosis sayur daging ayam dicuci terlebih dahulu dan di fillet, kemudian dilakukan pemotongan dan perebusan sayuran serta pencampuran daging ayam dengan semua bumbu, Daging dan sayuran yang sudah halus di tambahkan dengan tepung tapioka, tepung maizena dan bahan lainnya dan dilakukan pengadukan hingga rata, adonan yang telah siap kemudian dimasukkan ke dalam mesin adonan sosis, lalu semprotkan ke dalam casing, tahap akhir mengukus sosis hingga matang. Berdasarkan pengujian yang meliputi uji organoleptik, uji kadar air, uji protein, uji kadar abu, uji karbohidrat, uji lemak, uji mikrobiologi metode MPN meliputi
\end{abstract}


E. coli mendapatkan nilai negatif, kapang mempunyai nilai 1,49 x 10 dan karbohidrat mendapat nilai lebih besar dari standart sosis.

Kata Kunci: Sosis, Brokoli, Wortel, Eksperimen

\section{PENDAHULUAN}

Sayuran merupakan sumber makanan yang mengandung gizi lengkap dan sehat. Sayuran penting untuk kesehatan, karena dapat memberi tenaga untuk melakukan aktivitas sehari-hari dan dapat menjaga kesehatan tubuh. Jenis sayuran yang sering dikonsumsi oleh masyarakat diantaranya adalah wortel, brokoli.

Masing-masing sayuran memiliki kandungan vitamin dan protein yang berbeda-beda. Sayuran kaya akan sumber vitamin dan mineral, tetapi apabila sayuran tersebut hanya dimakan dalam jumlah yang sedikit, maka manfaatnya sebagai sumber vitamin dan mineral tidak akan bermanfaat bagi tubuh. Wortel mengandung vitamin A yang baik untuk kesehatan mata. Selain vitamin A, wortel juga mengandung vitamin B1, B2, B3, B6, B9, dan C, kalsium, zat besi, magnesium, fosfor, kalium, dan sodium. Selain sayuran wortel terdapat juga sayuran brokoli yang terdapat kandungan lemak, protein, karbohidrat, serat, air, zat besi, kalsium, mineral, dan bermacam vitamin A, C, E, ribofalvin, nikotinamide.

Beberapa penelitian terkait pembuatan sosis diantaranya adalah penelitian yang dilakukan oleh Hairiyah dan Jubaidah (2016) tentang penentuan formulasi dan umur simpan sosis buah dengan penambahan tepung tapioka. Penelitian tersebut menyimpulkan bahwa formulasi terbaik dari masing-masing sosis buah yaitu produk sosis buah pisang, buah naga dan buah pepaya dengan perlakuan C (T50\% = 50 g tapioka: $50 \mathrm{~g}$ buah) dengan perolehan nilai rata-rata kesukaan tertinggi. Produk sosis buah pisang, buah naga dan pepaya mampu bertahan selama 15 hari dengan penyimpanan produk di dalam freezer pada suhu $1^{\circ} \mathrm{C}$.

Penelitian lainnya yang dilakukan oleh Asngari, dkk. (2016) tentang subtitusi tepung labu kuning terhadap kandungan vitamin A dan daya terima panelis pada sosis ikan nila. Penelitian tersebut menyimpulkan bahwa bahwa sosis ikan nila dengan persentase substitusi tepung labu kuning 20\% merupakan perlakuan 
terbaik ditinjau dari kandungan vitamin A. Persentase substitusi tepung labu kuning dapat meningkatkan kandungan vitamin A pada sosis ikan nila. Kandungan vitamin A sosis ikan nila dengan subtitusi tepung labu kuning dengan persentase $0 \%, 10 \%, 15 \%$ dan $20 \%$ berturut-turut yaitu $<0,01 \mu \mathrm{g} / \mathrm{g}, 0,9825 \mu \mathrm{g} / \mathrm{g}, 1,5025 \mu \mathrm{g} / \mathrm{g}$ dan $1,5375 \mu \mathrm{g} / \mathrm{g}$. Hasil uji organoleptik menunjukkan daya terima panelis terhadap sosis ikan nila dengan substitusi tepung labu kuning berkisar antara 5 (agak suka) sampai dengan 6,8 (suka).

Sosis merupakan makanan yang terbuat dari daging, lemak, bahan pengikat, bahan pengisi, air, garam, dan bumbu-bumbu yang cara penyelesaiannya dengan dikukus, Umumnya sosis dibuat dari daging sapi atau daging ayam, hal ini dikarenakan bahan tersebut banyak tersedia dipasaran dan disukai oleh semua kalangan usia. Olahan sosis sayur dapat menambah pilihan sosis di masyarakat dan menambah nilai gizi, maka perlu dilakukan pengganti dari bahan tesebut yaitu dengan menggunakan bahan dasar yang memiliki harga lebih ekonomis dan memiliki gizi khusus. Selain itu wortel dan brokoli terdapat pada daerah Jember dan sekitarnya, sehingga lebih mudah didapatkan. Pada penelitian ini peneliti melakukan pengujian mutu sosis sayur brokoli dan wortel berdasarkan SNI 1013820-1995.

\section{METODOLOGI PENELITIAN}

\section{Waktu dan Tempat}

Kegiatan penelitian ini dilaksanakan pada bulan Juni sampai Agustus 2017 bertempat di Jl. Mastrip PO. BOX 164 Jember, Politeknik Negeri Jember Laboratorium Pengolahan Pangan dan Laboratorium Analisis Pangan. Pengujian meliputi uji organoleptik, uji kadar air, uji protein, uji kadar abu, uji karbohidrat, uji lemak, uji mikrobiologi meliputi Escherichia coli (E. coli) dan kapang. 


\section{Penelitian Eksperimen}

Menurut Solso dan MacLin (2002), penelitian eksperimen adalah suatu penelitian yang di dalamnya ditemukan minimal satu variabel yang dimanipulasi untuk mempelajari hubungan sebab-akibat. Penelitian eksperimen erat kaitanya dalam menguji suatu hipotesis dalam rangka mencari pengaruh, hubungan, maupun perbedaan perubahan terhadap kelompok yang dikenakan perlakuan. Pada penelitian eksperimen ini peneliti melakukan perbandingan produk yang dibuat dengan persyaratan mutu SNI sosis.

\section{Pelaksanaan Penelitian}

Pembuatan sosis sayur hasil olahan dari sayur brokoli (Brassica oleracea L.) dan wortel (Daucus carota L.), dalam penelitian Sosis Sayur dilakukan, yaitu: pertama merupakan tahap awal penelitian. Pembuatan sosis sayur dilakukan dengan mencuci daging ayam dan memisahkan daging ayam dengan tulang (fillet), kemudian memotong dan merebus sayuran, serta mencampur daging ayam dengan semua bumbu. Daging dan sayuran yang sudah halus di tambahkan dengan tepung tapioka, tepung maizena dan bahan lainnya kemudian diaduk hingga rata. Adonan yang telah siap kemudian dimasukkan ke dalam mesin adonan sosis, lalu disemprotkan ke dalam casing dan selanjutnya dilakukan pengukusan hingga matang.

\section{Uji Organoleptik}

Menurut Rahayu (1998) penilaian organoleptik merupakan cara penilaian terhadap mutu atau sifat suatu komoditi dengan menggunakan formulir uji organoleptik sebagai instrument atau alat. Uji yang dilakukan adalah uji score sheet yang terdiri dari uji hedonik dan uji mutu hedonik terhadap warna, aroma, rasa dan kenampakan. Pengujian Organoleptik terdiri atas 15 Panelis Dalam uji hedonik ini menggunakan 5 skala hedonik yang menunjukkan angka kesukaan yaitu 5: sangat suka sekali, 4:sangat suka, 3: suka, 2: agak suka, 1:tidak suka. 


\section{Uji Kadar Air}

Penentuan kadar air merupakan salah satu bagian yang sangat penting, baik dalam processing maupun pemeriksaan raw material dan produk akhir karena berhubungan dengan zat padat yang terkandung dalam suatu bahan (Anonim, 2016). Adapun prosedur pelaksanaan kadar air adalah Timbang cawan kosong yang sudah di oven selama 15 menit dengan suhu $\pm 110^{\circ} \mathrm{C}$ (a gram), Timbang sampel sebanyak 1 - 2 gram dalam cawan yang telah diketahui beratnya (b gram), Keringkan sampel dalam oven bersuhu $\pm 110^{\circ} \mathrm{C}$ selama $3-5$ jam, Setelah dioven lalu didinginkan dalam eksikator selama 30 menit agar suhu konstan kemudian ditimbang. Perlakuan ini diulangi sampai tercapai berat konstan. Selisih setiap ulangan kurang dari $2 \mathrm{mg}$ (c gram). Perhitungannya sbb:

$$
\begin{aligned}
& \text { Kadar Air ( } \% \text { wb })=\text { b-c / b-a x 100\% } \\
& \text { Kadar air }(\% \text { db })=\text { b-c / c-a x 100\% }
\end{aligned}
$$

\section{Uji Kadar Abu}

Prosedur pelaksanaan kadar abu adalah Siapkan cawan pengabuan atau krus, kemudian panaskan dalam oven selama 30 menit, dinginkan dalam eksikator (a gram), Timbang sebanyak 3 - 10 gram sampel yang telah dihomogenkan dalam cawan tersebut, Kemudian pijarkan dalam tanur pengabuan sampai diperoleh abu berwarna putih keabuabuan. Pengabuan dilakuakn dua tahap, Tahap I pada suhu $400^{\circ} \mathrm{C}$ dan tahap selanjutnya pada suhu $550^{\circ} \mathrm{C}$. Untuk bahan yang mengandung air lebih dari $30 \%$ dilakukan pengeringan lebih dahulu yaitu dengan pengovenan atau pemijaran lampu bunsen. Dinginkan dengan membiarkan cawan dan abu tinggal di tanur pengabuan sampai suhu tanur mencapai $100^{\circ} \mathrm{C}$. Kemudian pindahkan ke dalam eksikator, dan timbang. Perhitungan sebagai berikut:

$$
\% \text { Abu total }=(\text { M2 }- \text { M0) } \times(100 /(M 1-M 2)) \times(100 /(100-H))
$$

Keterangan: $\quad \mathrm{M} 0=$ Bobot cawan kosong (gram)

$$
\begin{aligned}
& \text { M1 = Bobot cawan dan bahan (gram) } \\
& \text { M2 = Bobot cawan dan abu total (gram) } \\
& \text { H = Kadar air, persen bobot dari bahan yang bersangkutan }
\end{aligned}
$$




\section{Uji Kadar Lemak dan Minyak dengan Soxhlet}

Prosedur penentuan kadar lemak dan minyak adalah Timbang dengan teliti 5 gram bahan yang telah dihaluskan dan masukkan dalam kertas saring yang telah diketahui beratnya, kemudian dibungkus dengan rapi. Sampel yang telah dibungkus tadi dimasukkan dalam tabung soxhlet. Alat kondensor dipasang diatasnya dan labu lemak dibawahnya. Pelarut dietil eter atau petrolium benzene dituangkan secukupnya kedalam labu lemak. Setelah itu dilakukan refluk selama 5 jam. Pelarut yang ada didalam labu lemak didestilasi, kemudian ditampung. Selanjutnya tabung lemak yang berisi lemak hasil ekstraksi dikeringkan dalam oven pada suhu $105^{\circ} \mathrm{C}$. Setelah itu dikeringkan sampai berat konstan dan didinginkan dalam desikator, kemudian ditimbang. Perhitungan sbb:

$\%$ KadarLemak $=\frac{(\text { Berat lemak }- \text { berat ketas saring }) \times 100 \%}{\text { Beratsampel }}$

\section{HASIL DAN PEMBAHASAN}

\section{Hasil Uji Organoleptik}

Hasil Uji Hedonik

Berdasarkan uji organoleptik terhadap uji hedonik yang dilakukan pada sosis sayur, hasil panelis dapat dilihat pada gambar 1 .

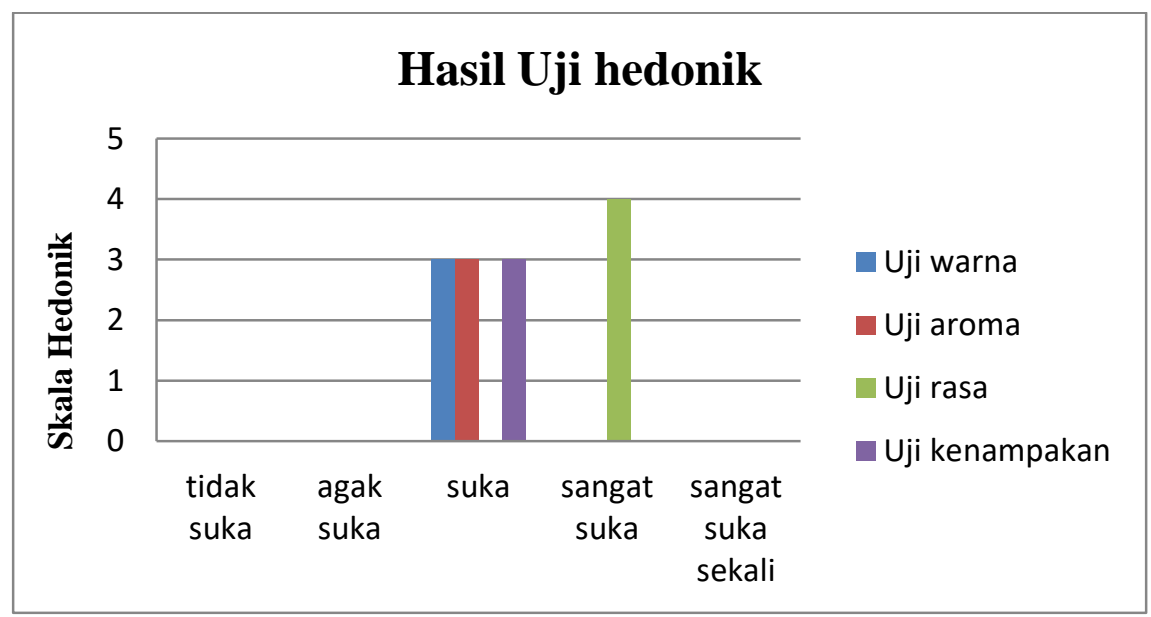

Gambar 1. Hasil Uji Hedonik warna aroma rasa dan kenampakan

Pada pengujian hedonik parameter warna, aroma dan kenampakan sosis sayur panelis memberikan nilai suka terhadap sosis sayur, selanjutnya panelis memberikan nilai sangat suka terhadap rasa sosis sayur. 
a. Warna

Berdasarkan gambar diatas terlihat bahwa panelis memberikan penilaian suka terhadap warna. Warna yang dihasilkan pada sosis sayur dapat dipengaruhi saat blanching yang dilakukan, sehingga tingkat kesukaan panelis terhadap warna sosis sayur berbeda. Pada dasarnya penilaian skala kesukaan ini bersifat subyektif jadi penilaianya tergantung dari panelis. Blanching adalah proses pemanasan bahan pangan dengan uap atau air panas secara langsung pada suhu kurang dari $100{ }^{\circ} \mathrm{C}$ selama kurang dari 10 menit. Fungsi Blanching adalah untuk menginaktifkan enzim yang tidak diinginkan yang mungkin dapat merubah warna, tekstur, citarasa maupun nilai nutrisinya. (Muchtadi, 2014)

\section{b. Aroma}

Berdasarkan gambar diatas terlihat bahwa panelis memberikan penilaian suka terhadap aroma. Kecenderungan ini disebabkan oleh semakin tingginya rasio daging ayam dan sayur brokoli dan juga wortel yang ditambahkan maka konsentrasi lemak yang terkandung didalam daging ayam juga akan meningkat sehingga dengan meningkatnya penambahan rasio daging ayam kedalam adonan bahan sosis sayur maka akan meningkatkan nilai hedonik aroma.

c. Rasa

Berdasarkan gambar diatas terlihat bahwa panelis memberikan penilaian suka terhadap rasa. Lemak pada daging ayam berfungsi sebagai pemberi citarasa pada makanan, karena pada saat proses pemanasan lemak akan terdekomposisi dengan protein. Lemak memberi citarasa lebih tahan dan memuaskan pada makanan yang dikonsumsi. (Yuni, 2003)

\section{d. Kenampakan}

Berdasarkan gambar diatas terlihat bahwa panelis memberikan penilaian suka terhadap kenampakan. Pada gambar diatas terlihat bahwa pengaruh tepung maizena dan tepung tapioka maka akan menaikkan nilai hedonik kenampakan pada sosis sayur. Sebaliknya semakin besar rasio daging ayam semakin turun nilai hedonik kenampakan sosis sayur. Keelastisan produk sosis ikan nila dipengaruhi oleh formulasi jumlah daging ikan dengan bahan pengisi dan lama proses pemasakan. Sosis dengan bahan pengisi tepung tapioka dan tepung labu kuning mempunyai 
nilai uji lipat tinggi, jika dibandingkan dengan yang hanya mengunakan bahan pengisi tepung tapioka atau tepung labu kuning saja. (Asngari, 2016)

\section{Uji Mutu Hedonik}

\section{a. Warna}

Berdasarkan uji organoleptik terhadap uji mutu hedonik warna yang dilakukan pada sosis sayur, hasil panelis dapat dilihat pada gambar 2.

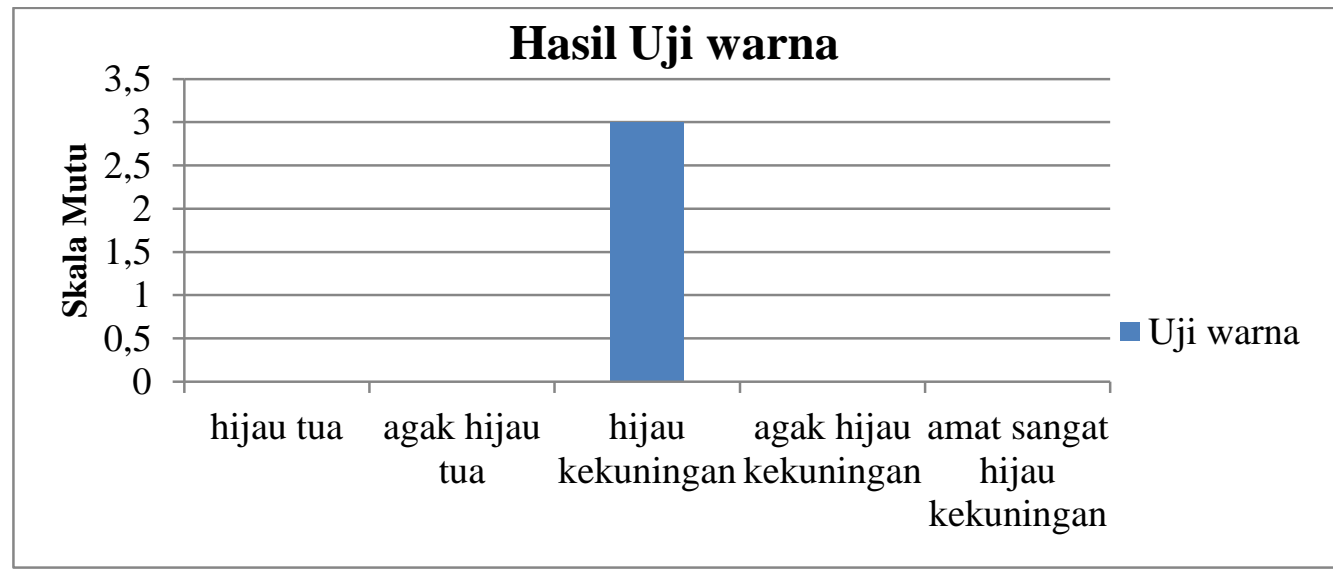

Gambar 2. Hasil uji mutu hedonik warna

Daging ayam memiliki kandungan mineral. Mineral dalam daging berasosiasi dengan tepung maizena, terutama yang tidak mengandung lemak, mineral yang tidak larut akan berasosiasi dengan protein, karena mineral yang larut lebih berasosiasi dengan daging yang tidak mengandung lemak ini adalah penyebab terjadinya warna. Panelis memberikan nilai hijau kekuningan pada uji mutu hedonik warna. Penelitian sosis ikan Nila menggunakan daging ikan nila yang berwarna putih dengan substitusi tepung labu kuning yang berwarna kuning. Sehingga semakin banyak persentase tepung labu kuning yang ditambahkan pada adonan sosis, maka warna kuning yang dihasilkan akan semakin cemerlang. (Asngari, 2016)

\section{b. Aroma}

Berdasarkan uji organoleptik terhadap uji mutu hedonik aroma yang dilakukan pada sosis sayur, hasil panelis dapat dilihat pada gambar 3. 


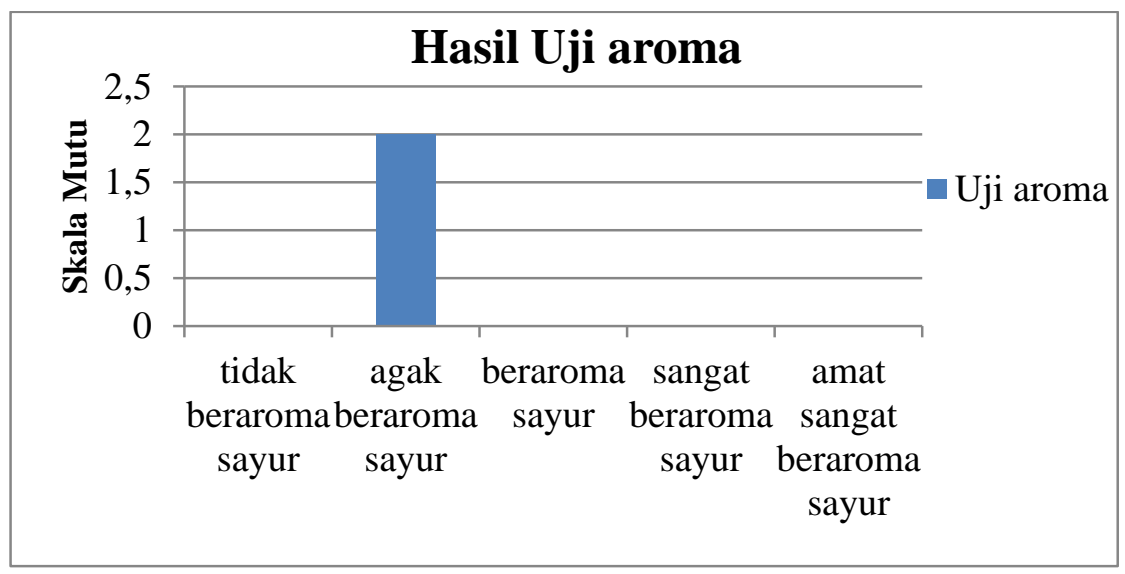

Gambar 3. Hasil uji mutu hedonik aroma

Aroma produk sosis sayur selain didapat dari aroma asli daging ayam, brokoli dan wortel juga didapat dari perlakuan dan penambahan bumbu - bumbu pada saat pemasakan. Pengaruh penggunaan sayur brokoli dan wortel yang menyebabkan bau khas dari daging ayam akan tertutupi, sehingga tingkat kekuatan aroma daging ayam yang dihasilkan semakin berkurang. Panelis memberikan nilai agak beraroma sayur pada uji mutu hedonik aroma.

c. Rasa

Berdasarkan uji organoleptik terhadap uji mutu hedonik rasa yang dilakukan pada sosis sayur, hasil panelis dapat dilihat pada gambar 4.

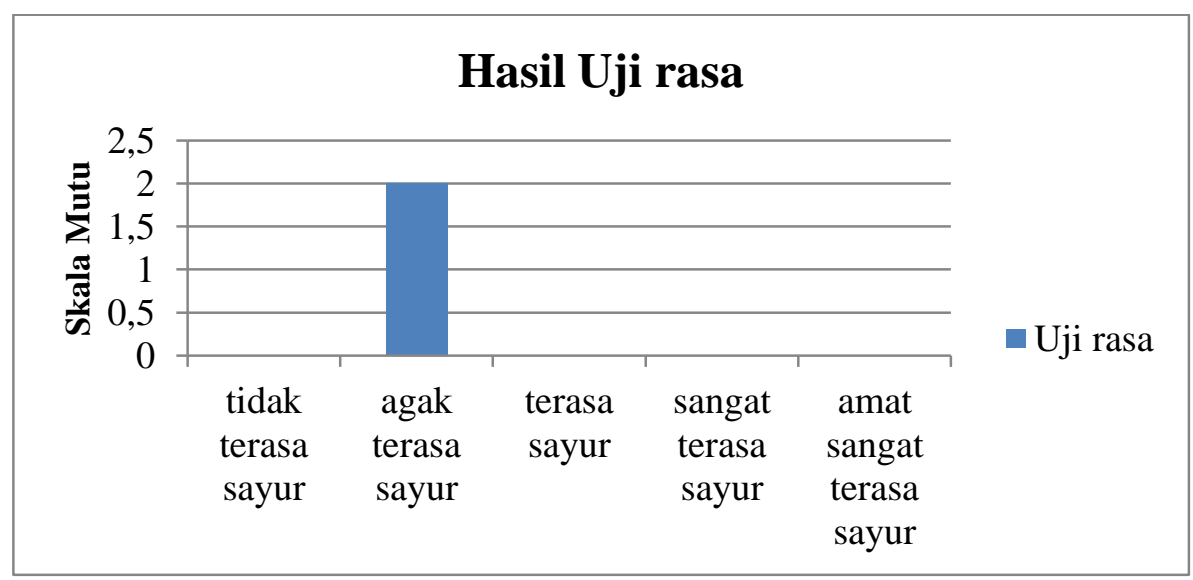

Gambar 4. Hasil uji mutu hedonik rasa

Daging ayam selain mengandung kadar lemak juga kaya akan senyawa senyawa pemberi citarasa. Lemak berfungsi sebagai pemberi citarasa pada makanan, karena pada saat proses pemanasan akan terdekomposisi dengan protein. 
Lemak memberi citarasa lebih tahan dan lebih memuaskan pada makanan yang dikonsumsi. Panelis memberikan nilai agak terasa sayur pada uji mutu hedonik rasa.

d. Kenampakan

Berdasarkan uji organoleptik terhadap uji mutu hedonik kenampakan yang dilakukan pada sosis sayur, hasil panelis dapat dilihat pada gambar 5.

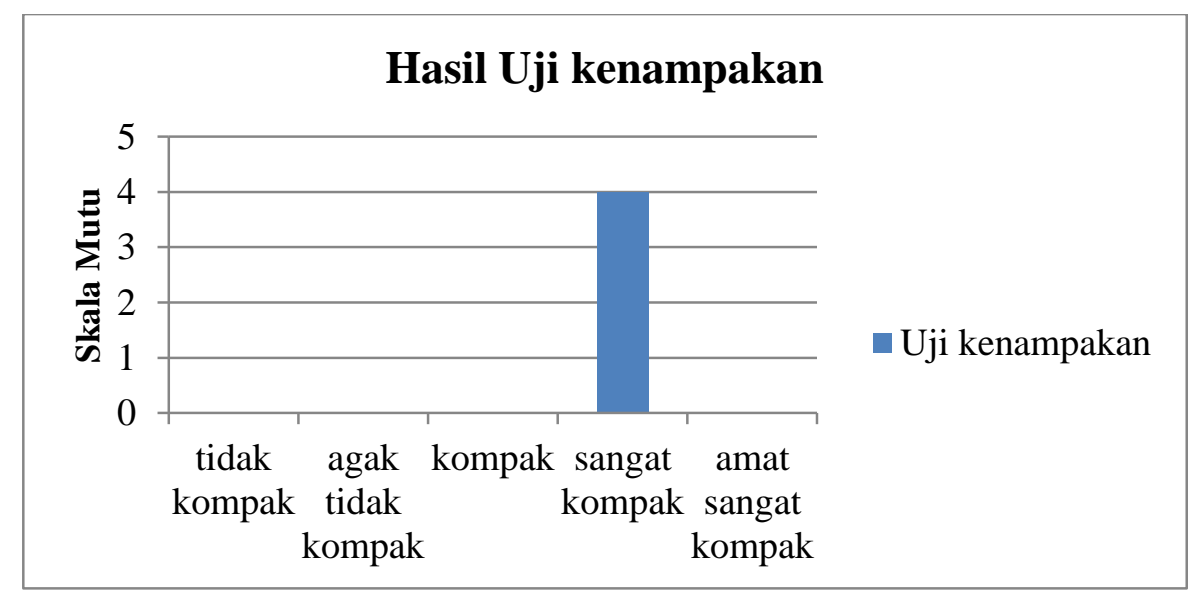

\section{Gambar 5. Uji mutu hedonik kenampakan}

Semakin besar rasio sayur brokoli dan wortel ditambah pada komposisi, cenderung menaikkan nilai mutu hedonik kenampakan pada sosis sayur. Sedangkan semakin tinggi rasio daging ayam yang digunakan cenderung memiliki nilai mutu hedonik kenampakan yang kurang baik. Kecenderungan semakin tingginya konsentrasi tepung maizena dan tepung tapioka terhadap mutu hedonik kenampakan yang semakin rendah nilai kenampakanya. Panelis memberikan nilai sangat kompak pada uji mutu hedonik kenampakan.

\section{Uji Kimia Syarat Mutu Sosis Daging}

Tabel 1. Hasil Uji kimia sosis sayur dan Persyaratan Mutu SNI Sosis

\begin{tabular}{lcc}
\hline \multicolumn{1}{c}{ Jenis Uji } & Hasil & $\begin{array}{c}\text { Persyaratan Mutu SNI } \\
\text { Sosis }\end{array}$ \\
\hline Kadar air (\%) & 66.495 & Maks. 67 \\
Kadar abu (\%) & 1.26 & Maks. 3 \\
Kadar lemak $(\%)$ & 1.38 & Maks. 25 \\
Protein (\%) & 14.88 & Min. 12 \\
Karbohidrat (\%) & 15.985 & Maks. 8 \\
Tekstur & 17.089 & - \\
\hline
\end{tabular}

Keterangan : Angka-angka ditabel merupakan hasil pengujian kimia sosis sayur dan standar mutu SNI sosis 


\section{a. Kadar air}

Pada table 1. Hasil pengujian kadar air sosis sayur mendapatkan nilai sebesar $66.49 \%$, masih lebih kecil apabila dibandingkan dengan syarat mutu SNI sosis maksimal 67\%. Dari hasil pengujian kadar air diatas, sosis sayur memenuhi standar mutu SNI sosis. Semakin tinggi konsentrasi daging ayam yang digunakan cenderung mempertahankan kadar air sosis sayur. Kecenderungan ini disebabkan oleh tingginya konsentrasi daging ayam yang digunakan sehingga dengan meningkatnya penambahan konsentrasi daging ayam kedalam adonan bahan sosis sayur maka akan meningkatkan kadar air sosis sayur.

\section{b. Kadar abu}

Pada Tabel 1. Hasil pengujian kadar abu mendapatkan nilai sebesar 1.26\%, masih lebih kecil apabila dibandingkan dengan syarat mutu SNI sosis maksimal 3\%. dari hasil pengujian kadar abu diatas, sosis sayur memenuhi standar mutu SNI sosis. Pada saat proses pembakaran, air pada bahan akan teruap secara keseluruhan, sehingga semakin besar kandungan air pada bahan maka pada saat pembakaran proses penguapan oleh air akan semakin besar dan sisa dari pembakaran akan semakin kecil, hal ini yang menyebabkan kadar abu pada sosis sayur cenderung kecil.

\section{c. Kadar lemak}

Pada Tabel 1. Hasil pengujian kadar lemak mendapatkan nilai sebesar 1.38\%, masih lebih kecil apabila dibandingkan dengan syarat mutu SNI sosis maksimal $25 \%$. Dari hasil pengujian kadar lemak diatas, sosis sayur memenuhi standar mutu SNI sosis. Ketengikan terjadi bila komponen citarasa dan bau yang mudah menguap terbentuk sebagai akibat kerusakan oksidatif dari lemak dan minyak yang tak jenuh. Komponen-komponen ini menyebabkan bau dan citarasa yang tak diinginkan dalam lemak dan minyak dan produk-produk yang mengandung lemak dan minyak itu. (Buckle, 1983)

\section{d. Protein}

Pada Tabel 1. Hasil pengujian kadar protein mendapatkan nilai sebesar $14.88 \%$, lebih besar apabila dibandingkan dengan syarat mutu SNI sosis minimal 12\%. dari hasil pengujian Protein diatas, sosis sayur memenuhi standar mutu SNI 
sosis. Semakin meningkatnya rasio daging ayam yang digunakan, cenderung memiliki kadar protein yang lebih tinggi. Hal ini disebabkan oleh semakin tingginya konsentrasi daging ayam yang digunakan sehingga dengan meningkatnya penambahan konsentrasi daging ayam kedalam adonan bahan maka akan meningkatkan kadar protein sosis sayur. Pada daging ayam memiliki kandungan protein yang cukup tinggi, sehingga apabila jumlah daging yang digunakan dalam adonan tinggi akan menyebabkan kandungan protein sosis juga tinggi (Poedjiadi, 1994).

\section{e. Karbohidrat}

Pada Tabel 1. Hasil pengujian kadar karbohidrat mendapatkan nilai sebesar $15.985 \%$, lebih besar apabila dibandingkan dengan syarat mutu SNI sosis maksimal 8\%. Dari hasil pengujian Karbohidrat diatas, sosis sayur tidak memenuhi standar mutu SNI sosis.Karbohidrat pada wortel segar mempunyai kandungan $10,14 \mathrm{mg} / 100 \mathrm{gr}$ wortel segar, sedangkan pada brokoli mempunyai kandungan 6,64gr/100gr. Tingginya kadar karbohidrat dapat mempengaruhi kekenyalan pada sosis.

\section{f. Tekstur}

Pengamatan tekstur selama penelitian menggunakan alat Penetrometer. Parameter tekstur biasanya diartikan dengan istilah keempukan dan kekerasan. Tekstur dalam hal tingkat kekerasan dan keempukan bahan ada hubungannya dengan jumlah kandungan air, dimana produk dengan jumlah kandungan air tinggi akan lebih lembek dibandingkan dengan produk yang kandungan airnya rendah.

Tekstur merupakan sifat sensoris produk yang berkaitan dengan tingkat kehalusan dari bahan-bahan yang digunakan pada penelitian pembuatan sosis sayur. Panca indera yang berperan dalam uji organoleptik spesifikasi tekstur adalah indera peraba dan menggunakan alat tekstur meter (Asngari, 2016). Tekstur yang kurang halus ini diduga disebabkan tepung tapioka yang digunakan kurang halus ukuran partikelnya dibandingkan dengan tepung maizena. Menurut Hadiwiyoto (1983) tekstur yang baik dari sosis yaitu tekstur yang kompak. 


\section{Uji mikrobiologi}

Tabel 2. Pengujian mikrobiologi sosis sayur

\begin{tabular}{lcc}
\hline Jenis sampel & Hasil analisa & $\begin{array}{c}\text { Persyaratan Mutu } \\
\text { SNI Sosis }\end{array}$ \\
\hline E.coli & Negatif & $<3$ \\
Total bakteri (cfu/gr) & $6,6 \times 10$ & - \\
Kapang (cfu/gr) & $1,49 \times 10$ & Maks. 1,0 x 10 \\
\hline
\end{tabular}

Keterangan : Angka-angka ditabel merupakan hasil pengujian mikrobiologi sosis sayur dan standar mutu SNI sosis.

\section{E. coli}

Pada Tabel 2. Hasil pengujian E.coli mendapatkan nilai negatif, Persyaratan Mutu SNI Sosis nilai Maks. < 3 APM/g, dari pengujian didapatkan hasil yang negatif dari Persyaratan Mutu SNI Sosis. Keadaan fisik sosis setelah lebih dari 15 hari mengalami perubahan yang sangat mencolok hal ini dikarenakan adanya aktifitas mikroba dan meningkatnya kadar air pada produk sehingga menyebabkan produk sosis mengalami perubahan pada rasa, aroma, warna dan tekstur. Menurut Karlah (2014), peningkatan jumlah mikroorganisme yang tumbuh selama masa penyimpanan dapat diakibatkan karena adanya kenaikan kadar air pada produk. Kenaikan kadar air akan meningkatkan aktivitas air (aw) produk. Perubahan tersebut juga dapat dibuktikan dengan melakukan uji E.coli terhadap produk sosis sayur dengan melakukan uji E. coli terhadap produk sosis yang telah mengalami perubahan fisik, setelah dilakukan uji E.coli maka didapatkan hasil yaitu Negatif.

\section{Kapang}

Pada Tabel 2. Hasil pengujian kapang mendapatkan nilai $1,49 \times 10$, Persyaratan Mutu SNI Sosis nilai Maks. 1,0 x 10, dari pengujian didapatkan hasil yang lebih tinggi dari Persyaratan Mutu SNI Sosis. Uji mikrobiologi dengan cara Total Plate Count (TPC) dimaksudkan menghitung jumlah bakteri pada produk sosis. Pada penelitian ini menunjukkan hasil dari keseluruhan perlakuan yaitu spreeder. Oleh karena itu selanjutnya dilakukan pengujian pewarnaan gram untuk mengetahui jenis spesies bakteri yang tumbuh pada sosis tersebut. Hasil pewarnaan 
gram didapatkan koloni bakteri yang tumbuh pada sosis adalah bakteri jenis gram negatif (-), dengan bentuk basil (batang).

Bakteri gram negatif (-) adalah bakteri yang tidak mempertahankan zat warna kristal violet sewaktu proses pewarnaan gram, sehingga akan bewarna merah bila diamati dengan mikroskop. Bakteri gram negatif memiliki sistem membran ganda dimana membran plasmanya diselimuti oleh membran luar permeabel. Bakteri ini mempunyai dinding sel tebal berupa peptidoglikan, yang terletak di antara membran dalam dan membran luarnya (Anonim, 2016).

\section{KESIMPULAN}

Berdasarkan hasil penelitian Eksperimen Sosis Sayur Hasil Olahan Dari Sayur Brokoli Dan Wortel dapat disimpulkan bahwa:

Pembuatan sosis sayur hasil olahan dari sayur brokoli dan wortel dilakukan Pengujian meliputi uji organoleptik hedonik dan mutu hedonik, Pada pengujian hedonik parameter warna, aroma dan kenampakan sosis sayur panelis memberikan nilai suka terhadap sosis sayur, selanjutnya panelis memberikan nilai sangat suka terhadap rasa sosis sayur.

Uji kadar air mempunyai nilai 66.49\%, syarat mutu sosis kadar air Maks. $67 \%$, uji protein mempunyai nilai $14.88 \%$, syarat mutu sosis protein Min. $12 \%$, uji kadar abu mempunyai nilai $1.26 \%$, syarat mutu sosis kadar abu Maks. 3\%, uji karbohidrat mempunyai nilai 15.98\%, syarat mutu sosis karbohidrat Maks. 8\%, uji lemak mempunyai nilai $1.38 \%$, syarat mutu sosis lemak Maks. 25\%, uji mikrobiologi meliputi E. Coli mendapatkan nilai negatif, Persyaratan Mutu SNI Sosis nilai Maks. < 3 APM/g dan kapang mempunyai nilai 1,49 x 10, Persyaratan Mutu SNI Sosis nilai Maks. 1,0 x 10, uji karbohidrat mempunyai nilai uji lebih besar dari standar mutu sosis. 


\section{UCAPAN TERIMAKASIH}

Kami sampaikan ucapan terimakasih atas terselesaikannya penelitian ini kepada: Dr. Ir. Nanang Dwi Wahyono, MM., Direktur Politeknik Negeri Jember. Dr. Ir. Budi Hariono, M.Si, Kepala Pusat Penelitian Pengabdian Kepada Masyarakat. Tim Reviewer Pusat Penelitian Pengabdian Kepada Masyarakat, Dr. Ir. Merry Muspita DU. Dan Hendra Yufit R., M.CS. PLP Laboratorium Analisis Pangan dan Laboratorium Pengolahan Pangan. Semua Pihak yang membantu penyelesaian penelitian.

\section{DAFTAR PUSTAKA}

Buckle, K.A. (1983). Ilmu Pangan. Diterjemahkan oleh Hari Purnomo dan Adiono. Universitas Indonesia Press. Jakarta.

Hadiwiyoto S. (1983). Susu, daging, Telur Dan Hasil Olahannya. Liberty Yogyakarta.

Hairiyah, Nina., Jubaidah (2016). Penentuan Formulasi Dan Umur Simpan Sosis Buah Dengan Penambahan Tepung Tapioka. Jurusan Teknologi Industri Pertanian. Politeknik Negeri Tanah Laut.

Hasyim Fu'ad, A., Agustiana, Hafni Rahmawati, (2016). Substitusi Tepung Labu Kuning (Cucurbits Moschata, Durch) Terhadap Kandungan Vitamin A Dan Daya Terima Panelis Pada Sosis Ikan Nila (Oreochromis Niloticus). Fish Scientiae, Volume 6 Nomor 2, Desember 2016, hal 38-38.

Karlah L. R., Mansauda, Fatimawali, Kojong, N. (2014). Analisis Cemaran Bakteri Coliform Pada Saus Tomat Jajanan Bakso Tusuk Yang Beredar Di Manado. Manado.

Muchtadi R. Tien, Sugiyono. (2014). Prinsip Proses dan Teknologi Pangan. Alfabeta Bandung.

Poedjiadi Anna. (1994). Dasar-dasar biokimia. UI-PRESS. Jakarta.

Rahayu. (1998). Penuntun Praktikum Penelitian Organoleptik. Bogor. IPB.

Solso, R. L MacLin, M. K, O. H. (2005). Cognitive Psychologi. New York. Pearson

Sri Yuni dan Nur Aeni Khalid. (2003). Mencari Formulasi Pembuatan Fish Nugget yang baik. Jember. Politeknik Negeri Jember. 
Wahyono, A. (2016) Analisis kimia pangan. Program studi Teknologi industri pangan. Politeknik Negeri Jember. Jember.

Wahyono, A. (2016). Higiene dan Sanitasi. Program studi Teknologi industri pangan. Politeknik Negeri Jember. Jember.

(BSN) Badan Standarisasi Nasional SNI 101-3820-1995 tentang sosis daging http://sisni.bsn.go.id.(Diakses tanggal 25 Agustus 2017). 